\title{
Grasslands of Northern Europe and the Baltic States
}

\section{Dengler, Jürgen}

Elsevier, Oxford

2020-06

pÿDengler , J , Birge , T , Bruun , H H , Raaomaviius , V , RksiFa, S \& Sickel , H 2020 , Grasslands of Northern Europe and the Baltic States . in M Goldstein \& D DellaSala (eds), Encyclopedia of the World's Biomes . 1. edn , Elsevier, Oxford , pp. 689-702 . https://doi.org/10.1016/B978-0-12-409

http://hdl.handle.net/10138/326678

https://doi.org/10.1016/B978-0-12-409548-9.12433-9

cc_by_nc_nd

acceptedVersion

Downloaded from Helda, University of Helsinki institutional repository.

This is an electronic reprint of the original article.

This reprint may differ from the original in pagination and typographic detail.

Please cite the original version. 
Chapter for Encyclopedia of the World's Biomes, Section 8-Grasslands and Shrublands

\section{Grasslands of Northern Europe and the Baltic States}

Jürgen Dengler, Traci Birge, Hans Henrik Bruun, Valerijus Rašomavičius, Solvita Rūsiṇa \& Hanne Sickel

This chapter was solicited and edited by Jürgen Dengler and Péter Török on behalf of the Eurasian Dry Grassland Group (EDGG)

\section{Author addresses}

Jürgen Dengler (Corresponding; ORCID: https://orcid.org/0000-0003-3221-660X):

(a) Vegetation Ecology, Institute of Natural Resource Management (IUNR), Zurich University of Applied Sciences (ZHAW), Grüentalstr. 14, 8820 Wädenswil, Switzerland

(b) Plant Ecology, Bayreuth Center of Ecology and Environmental Research (BayCEER), University of Bayreuth, Universitätsstr. 30, 95447 Bayreuth, Germany

(c) German Centre for Integrative Biodiversity Research (iDiv) Halle-Jena-Leipzig, Deutscher Platz 5e, 04103 Leipzig, Germany

E-mail: juergen.dengler@uni-bayreuth.de

Traci Birge (ORCID: https://orcid.org/0000-0002-4730-981X):

HELSUS Helsinki Institute of Sustainability Science and Department of Agricultural Sciences, University of Helsinki, P.O. Box 27, 00014 Helsinki, Finland

E-mail: traci.birge@gmail.com

Hans Henrik Bruun (ORCID: https://orcid.org/0000-0003-0674-2577):

Department of Biology, University of Copenhagen, Universitetsparken 15, 2100 Copenhagen

E-mail: $\underline{\text { hhbruun@bio.ku.dk }}$

Valerijus Rašomavičius (ORCID: https://orcid.org/0000-0003-1314-4356):

Nature Research Centre, Institute of Botany, Žaliuju Ežeru Str. 49, 08406 Vilnius, Lithuania E-mail: valerijus.rasomavicius@gamtc.It

Solvita Rūsiṇa (ORCID: https://orcid.org/0000-0002-9580-4110):

Faculty of Geography and Earth Sciences, University of Latvia, Jelgavas iela 1, Riga, 1004, Latvia E-mail: solvita.rusina@lu.lv

Hanne Sickel:

Department of Landscape Monitoring, Norwegian Institute of Bioeconomy Research, Postboks 115, NO-1431 Ås, Norway

E-mail: hanne.sickel@nibio.no 


\section{[6592 words, 92 references, 2 figures, 3 tables]}

\section{Keywords}

Baltic States; biodiversity; conservation; grassland; grazing; high nature value farmland; intensified grassland; management; meadow; Natura 2000; natural grassland; Nordic countries, Northern Europe; pasture; semi-natural grassland

\section{Synopsis (50-100-word abstract for online presentation)}

In the Nordic-Baltic region of Europe, grasslands cover ca. $7 \%$ of the study region, half of which are natural grasslands (mostly arctic-alpine, to a smaller extent also azonal and extra-zonal) and the other half secondary grasslands created by human land use (livestock grazing or haymaking). Both grassland categories have high importance for biodiversity in many taxa. However, particularly the secondary grasslands are profoundly negatively affected by area loss (conversion to other land uses) and quality loss (mainly due to intensification and to abandonment). Conservation measures typically try to mimic traditional low-intensity land uses that are agronomically not profitable anymore. 


\section{Abstract (longer abstract for print)}

This chapter deals with the grasslands of Northern Europe (Denmark, Faroe Islands, Finland, Iceland, Norway, Sweden) and the Baltic States (Estonia, Latvia, Lithuania), with a focus on natural and seminatural grasslands of the lowlands, thus treating arctic-alpine and strongly intensified types only marginally. At present, grasslands cover ca. 7\% of the study region, half of which are natural grasslands (mostly arctic-alpine, to a smaller extent also azonal and extra-zonal) and the other half secondary grasslands created by human land use (livestock grazing or haymaking). Both grassland categories have high importance for biodiversity in many taxa. However, particularly the secondary grasslands are profoundly negatively affected by area loss (conversion to other land uses) and quality loss (mainly due to intensification and to abandonment). Conservation measures typically try to mimic traditional low-intensity land uses that are agronomically not profitable anymore.

\section{Delimitation and environmental conditions of the region}

We define "Northern Europe and the Baltic States" here based on political territories: Iceland, Faroe Islands, Norway, Sweden, Finland, Denmark, Lithuania, Latvia and Estonia. With the exception of the British Isles which are treated in the Western European grassland chapter of the "Encyclopedia of the World's Biomes" (Boch et al. 2020), this definition corresponds to "Northern Europe" in the UN Geoscheme. This geographic unit comprises the northern parts of the "Western and Northern European" treatise (Dengler and Tischew 2018) in the global grassland book (Squires et al. 2018) together with the three Baltic States, which in the book were included in the Eastern European chapter (Török et al. 2018). In this chapter, "Nordic-Baltic region" or "the region" refers to Northern Europe and the Baltic States combined. "Northern Europe" (sometimes also called "Nordic countries": Denmark, Faroe Islands, Finland, Iceland, Norway, Sweden) and "Baltic States" (Estonia, Latvia, Lithuania) are used to address the two subregions, respectively. Ecologically, the subregions are similar (with differentiation mainly following a North-South gradient), but they differ in land-use history during the 20th century as the Baltic States were part of the communist Soviet Union. Further, we use "Fennoscandia", which refers in this chapter to the three countries on the Fennoscandian Peninsula, Norway, Sweden, Finland) but excluding Russian territory along the peninsula because these are addressed in Tishkov et al. 2020).

The overall territory of the study region is 1.484 million $\mathrm{km}^{2}$, extending from 54 to $81^{\circ}$ northern latitude and from $25^{\circ}$ western to $32^{\circ}$ eastern longitude (Table 1 ). The territory is inhabited by nearly 30 million people but population density varies tremendously from as high as 135 persons $/ \mathrm{km}^{2}$ in Denmark in the south to only 3.5 persons $/ \mathrm{km}^{2}$ in Iceland in the north (Table 1). Most parts of the territory are flat to hilly lowland, with the only exception of Iceland, which is a volcanic island with a maximum elevation of $2110 \mathrm{~m}$ a.s.l., and the Scandes, covering most of Norway and the westernmost parts of Sweden and reaching an elevation of 2,469 $\mathrm{m}$ a.s.l.

\section{$<$ Table 1 approximately here>}

The climate of the region is very mild for its latitude due to the Gulf Stream and the North Atlantic Drift, as well as due to dominating southwesterly winds. The climate is humid as there is cyclonic rain in all the seasons, with a maximum in late summer and autumn (Dahl 1998). According to the Köppen climate classification, most parts of Scandinavia experience a cold climate with cold summers and no drought (Dfc type and, in the far north, tundra climate ET type). However, most of Denmark, the southern parts of Finland and Sweden, and the Baltic States have cold climate with warm summers and no drought (Dfb type). Additionally, Southern Denmark lies in the temperate climate zone with warm summers (Cfb) (Peel et al. 2007). 
During the last (Weichselian) glaciation, the vast majority of the territory was covered by the Eurasian ice sheet complex and the separate Icelandic and Faroese ice sheets, with the exception of southwestern Denmark and tiny areas in southern Lithuania (Patton et al. 2017). From the last glacial maximum at $23 \mathrm{ka} \mathrm{BP}$, the ice shield retreated to reach the current status with only a few remaining mountain glaciers approx. 8.7 ka BP (Patton et al. 2017). However, the post-glacial rebound is still affecting the region today (Patton et al. 2017) particularly the Bay of Bothnia, where post-glacial land uplift at a maximum rate of more than $5 \mathrm{~mm}$ relative to sea level creates new terrestrial surfaces. Glaciation has influenced geomorphology of the region significantly and has created considerable diversity in the landscape.

Grasslands have developed on a variety of soils from calcite-bearing parent soils to acidic soils developed from sandstone, gneiss or granite. Mesic grasslands occur on deep soils formed on quaternary deposits. Fertile types of mesic meadows and pastures occur mostly on Luvisols, while poor pastures rather inhabit Planosols or Podzols, the latter being the most widespread soil type in Fennoscandia. Semi-dry and rocky grasslands most commonly develop on shallow calcareous soils (Leptosols) which reach their greatest coverage in the Baltic Sea islands, southern Sweden, and western Estonia. Arenosols support dry sandy grasslands and mesic nutrient-poor Nardus grasslands across the region but they are the most widespread in Sweden and in parts of Latvia, Lithuania, and Denmark. Floodplain grasslands grow mostly on Fluvisols, which are common in Baltic States but less frequent in Fennoscandia. Moist and wet grasslands are commonly found on Gleysols, Estonia being the richest in such areas, and Histosols (Reimann et al. 2003; Jones et al. 2005; Tóth et al. 2008).

\section{Biogeography, flora and fauna}

Due to the humid climate, forests form the zonal vegetation in most of Northern Europe and the Baltic States. Regions with short periods of frost (Denmark, southernmost tip of Norway and Sweden) belong to the nemoral zonobiome (ZB VI), which are naturally dominated by broad-leaved forests (Walter and Breckle 1986). Regions further north with longer winters and cooler summers (most of Sweden and Finland) are classified as boreal zonobiome (ZB VIII) and naturally covered by coniferous forests (Walter and Breckle 1986). Between both zonobiomes, a transition zone, the so-called boreonemoral zone (zonoecotone VI-VIII) occurs where broad-leaved and coniferous trees jointly form the tree layer (Baltic States, south Finland, south Sweden, non-alpine parts of Norway). In the northernmost tip of Fennoscandia, the Scandes and Iceland, the tundra biome prevails (ZB IX sensu Walter and Breckle 1986).

The study region comprises four floristic provinces (Finnie et al. 2007). The Northern European province coincides with the boreal zonobiome. The border of Central European and Eastern European province runs through the territory of Baltic States. The western parts of Denmark and the most southwestern tip of Norway belong to Atlantic European province. Phytogeographers of the Baltic States argue for the delimitation of a separate Baltic province. The southwestern boundary of the Baltic province coincides with the boundary of the boreonemoral zone. The northern boundary of the continuous Carpinus betulus distribution range is the outline of the transition of the Baltic province into the Central European province. The distributional boundary of several continental species, such as Koeleria glauca, Astragalus arenarius, Pulsatilla pratensis, P. patens and Silene chlorantha, marks the southeastern boundary with the Eastern European province (Eilart 1975).

The flora and fauna of the region is "under-saturated" with species because of the recent glaciations, which "reset" the biota. Immigration of species after the retreat of glacial sheet is still ongoing, and the limited duration of the postglacial period has provided limited opportunity for in-situ speciation 
(Dahl 1998). The floristic elements of northern Europe tend to be composed of wide-ranging species and include only a low proportion of European endemics (Finnie et al. 2007). The endemics of the region are mostly infraspecific taxa in apomictic polymorphous groups or allopolyploids, with only a few being accepted at the rank of species (Dahl 1998; Jonsell and Karlsson 2004). Grasslands comprise several such endemics, especially on the islands of the Baltic Sea. They are, for instance, Helianthemum oelandicum subsp. oelandicum, Galium oelandicum, Festuca oelandica, Crepis tectorum subsp. pumila, and Allium schoenoprasum var. alvarense (Dengler et al. 2006). A second "hotspot" of endemism are the Baltic shores, mostly with grassland taxa (Jonsell and Karlsson 2004). In Finland, seashore meadows are a habitat type for which the country has an international responsibility. The seashore meadows are important for endemic species, and Finland's international responsibility stems from the uniqueness of the post-glacial land uplift quality of the seashore meadows (Lehtomaa et al. 2018).

The biota outside the glacial limits were also affected by cold and arid climate during the Pleistocene. Nevertheless, the lack of glaciation in southwestern Denmark and southern Lithuania (Patton et al. 2017) resulted in comparatively high species richness there (Lawesson and Skov 2002). Similarly, the dune heath of the Atlantic province is a special responsibility for Denmark, harbouring a few endemic species, such as Euphrasia dunensis (see Jonsell and Karlsson 2004) and the grasshopper Corthippus jutlandica.

\section{Origin of the grasslands}

In the region, natural arctic-alpine grasslands are widespread in the tundra biome. Azonal and extrazonal natural grasslands, including steppe-like semi-dry grasslands, heathlands, and coastal grasslands on saline to brackish wet soils, occur throughout the region in areas where edaphic factors or natural disturbance hamper tree growth. However, grazing by large herbivores or surrogates thereof, nowadays livestock grazing and mowing, is essential for long-term stability of such grasslands. Semi-dry grasslands with floristic elements of steppe are especially abundant on the islands of Öland (Fig. 1e), Gotland and Saaremaa in the Baltic Sea. These islands are arguably the best candidates in the region for a zonoecotone between the nemoral and the arid-temperate continental zonobiome (ZB VII; Walter and Breckle 1986). Secondary grasslands, both semi-natural and intensified types, prevail in the two forest biomes and their zonoecotone. They have been created by clearing of forests and need regular mowing, livestock grazing or burning for their maintenance.

The origin of temperate grasslands in the Nordic-Baltic region is disputed. There are two main lines of reasoning. Habitats for the grassland biota may be naturally present in sufficient area coverage in mosaic with dominant forest and woodland (Svenning 2002), or - alternatively - grasslands of the region owe their existence entirely to human pastoralism and shifting agriculture from the Neolithic and onwards (Iversen 1973; Pott 1995). There is no doubt that human land use has radically expanded grassland habitats through the last few millennia, hence the term "semi-natural grassland" (Marquer et al. 2014). Likewise, there is little doubt that entirely open landscapes devoid of trees are cultural products. However, different lines of evidence suggest a long-term existence of habitat for grassland biotas in the region. Evidence from the Eem interglacial and earlier is very scarce, due to the resetting effects of the later Weichselian glaciation, almost entirely covering the region at its maximum (Patton et al. 2017). However, pollen assemblages in Eemian palaeosols from western Jutland have been found to contain a certain grassland element (Andersen 1965; Björck et al. 2000). It is thought that large herbivores - interacting with local climate and soil conditions - have influenced vegetation structure to allow a significant grassland element in the biotas (Svenning 2002; Sandom et al. 2014; Schweiger and Svenning 2018). The decline of the megafauna was already in an 
advanced state by the onset of the Holocene (Barnosky et al. 2004). Nonetheless, several palaeoecological studies have found that open vegetation persisted throughout the period in the Nordic-Baltic region (Nielsen et al. 2012; Theuerkauf et al. 2014; Hjelle et al. 2018) and the wider Western Palearctic (Sommer et al. 2011; Holm and Svenning 2014). However, palaeoecological methods have limited power in discrimination between open forests with a closed field layer ("savanna") or a mosaic of open grassland patches within dense forests ("forest steppe").

Just like under current conditions, grasslands or grassland-forest mosaics may have been more likely on certain soil types, such as more drought-prone calcareous and sandy soils (e.g. Theuerkauf et al. 2014), under certain conditions of topography, such as on steep slopes and potentially in places prone to wind-throw or wildfires (Kuosmanen et al. 2018). Furthermore, the isostatic land uplift in the Baltic region has continuously through the Holocene provided new land to become colonized by grassland biotas (Zobel and Kont 1992; Auffret and Cousins 2018).

The grassland flora of the Nordic-Baltic region is made up of plant species with an overall distributional center of gravity in Central Europe (Pärtel et al. 2005). Thus, the species of the current flora seem to have survived the Weichselian glacial maximum in Central and Eastern Central Europe and have re-immigrated from there. Recent reviews of landscape openness during the Holocene in Central Europe suggest the continuous presence of grassland habitat throughout the Holocene, as grasslands and open woodlands, and that the Neolithic pastoralism probably first expanded in landscapes that were already somewhat open (Hejcman et al. 2013; Kuneš et al. 2015).

Hay meadows came into existence much later. Animal husbandry started in Eastern Baltics only around 2900-2400 BC (Piličauskas et al. 2018), and the first scythes come from the Iron Age and are dated to the 3rd-4th century in the southeastern part of the Baltic region (Apals et al. 1974), and also Sweden, where the first finds of hay rakes date from the 3rd to 4th century (Pedersen and Widgren 2011).

\section{Types of grasslands}

Overall, the spatial extent of natural vs. secondary grasslands is similar, with approx. $50,000 \mathrm{~km}^{2}$ in each group (Table 1). Natural grasslands are found at large extents on Iceland but cover only rather small areas in the other countries (Table 1; see also Helgadóttir et al. 2014). Among the natural grasslands, arctic-alpine types prevail (Figs. 1a-b), while azonal and extrazonal types contribute less than $10 \%$ of the total area (Figs. 1c-e) and true steppes (in the sense of climatogenic grasslands in climates that are too dry for forests) are absent from the region (Table 1). Among the secondary grasslands, a majority nowadays are strongly intensified (Fig. 2b), while species-rich, so-called seminatural grasslands (Figs. 1e-h, 2a, 2c-2e) have become a minority (Table 1).

\section{<Fig. 1 approximately here> \\ $<$ Fig. 2 approximately here>}

Most of the countries in the region have national classification schemes for their grassland types. Norway, for example, recently adopted a new system called "Nature types in Norway"(NiN; https:// artsdatabanken.no/Pages/135563), which distinguishes 25 semi-natural grassland types along the three main gradients, soil pH, soil moisture and management (weak - strong). Finland, as another example, distinguishes 12 main types of semi-natural grasslands and grazed woodlands, which are collectively referred to in the country as traditional rural biotopes. These are: heaths, rock meadows, dry meadows, mesic meadows, moist meadows, freshwater meadows, seashore meadows, alluvial meadows, fen meadows, pollard meadows, wooded pastures and grazed woodlands (Kontula and 
Raunio 2018). In total, 42 sub-types of traditional rural biotopes were assessed in Finland for the 2018 Red List of Habitats (Lehtomaa et al. 2018). The Estonian vegetation site type classification includes four main grassland types (dry and fresh, floodplain, coastal, and paludified grasslands) with14 subtypes (Paal 1997). In Latvia and Lithuania, grassland classification follows phytosociological approach (Rašomavičius 1998; Rūsiña 2007). In Latvia, 16 habitat types at the alliance level are distinguished (Kabucis 2001), among which the dry and mesic grasslands include 23 associations (Rūsiṇa 2007).

For the sake of comparability, we provide here an overview of the main grassland types in the region based on the refined EUNIS grassland typology (Table 2), which can now be applied consistently across national borders via an electronic expert system (Schaminée et al. 2016). The same system also underlies the first Red List of Habitats in Europe (Janssen et al. 2016) and clearly connects to the priority habitats of the Habitats Directive of the European Union (European Commission 2013).

\section{$<$ Table 2 approximately here $>$}

\section{Management and agricultural policy}

During the period of traditional agriculture, the area of meadows was often greater than that of arable fields within the resource area of each village or isolated farm. The primary management of semi-natural grasslands in Northern Europe was through grazing and hay-making to provide winter fodder. In many cases in traditional agriculture in the Nordic and Baltic countries, animals were turned out to graze meadows only after hay was collected. Pollarding was once a common form of fodder collection in the Nordic countries and produced distinctive features in e.g. wooded pasture and grazed woodlands. Swiddening was practiced in some areas, leading, for example, to treeless heaths (Berglund et al. 2014). Collection of reeds for winter fodder was also practiced and was instrumental in keeping coastlines open. The grazing and fodder collection under traditional agriculture in Northern Europe created mosaic landscapes and is thought to have had a primarily positive impact on biological diversity at least up until the end of the 19th century (Pykälä 2001; Berglund et al. 2014). The existing semi-natural grasslands are the most important feature for biodiversity associated with farmlands in the Nordic-Baltic region.

Traditional farming in Scandinavia (lasting until approximately the end of the $19^{\text {th }}$ century) was based on an infield-outfield landscape, where inlands (often fenced) were used as field and hay meadow and outlands (unfenced) were used as pasture (Berglund et al. 2014). In the Baltic States, meadows were located mainly in river flood plains where spring floods ensured natural enrichment of soils. Outside flood-plains, meadows were situated in areas which were not suitable for arable land (e.g. too poor or too wet). The poorest land not suitable even for mowing was used pasture land. Fallowlands, fens, forest edges and forests were also grazed (Gustina 2016). Traditionally in Estonia wooded meadows and alluvial meadows were mown, wooded pastures, alvars, and coastal grasslands were used as pastures (Sammul et al. 2000).

Semi-natural grasslands are the result of centuries with domestic animals grazing natural vegetation types and the harvest of wild growing plant material used as fodder for cattle, sheep, horses and goats in the winter months (Emanuelsson 2009). The animals were normally kept indoors during cold winter months with snow, but were let out to graze as early in the spring as possible. The winter feed was often limited and nutritionally deficient. Thus, it was important to give the animals fresh plant material as soon as possible after the winter. Grazing often took place near the farms in the spring and autumn, but in the summer it was important to save the hay meadows so that they could be harvested for winter fodder. In Finland and the Baltic States, animals were usually allowed on to the 
hay meadows only after the hay had been harvested. Generally, the animals were herded into forests, heathland, mountain pastures, wetland or other natural vegetation. In Norway and Sweden, it was normal to move the husbandry to summer farms, situated in the subalpine vegetation zone of mountains or in woodland, where grazing resources were almost unlimited. On the summer farms, milk products such as cheese, butter and sour cream were produced, and winter fodder such as grasses, herbs, sedges, lichen, leaves and branches from bushes and trees were harvested (Reinton 1955). A huge amount of wood was needed as firewood on the summer farms and the landscape surrounding these farms were often open and treeless.

In an effort to make agriculture more efficient, governments replaced the traditional parceling systems for fields and meadows with land ownership based on contiguous property, starting, for example, already in the 18th century in Sweden and Finland. Policy encouraging specialization has played a significant role in the decline of biodiversity-rich semi-natural meadows in the Nordic and Baltic countries, with the loss of mixed farming and decline in small-holdings with a small number of ruminants leading to abandonment, afforestation, or conversion to arable fields. This process happened earlier in the Nordic countries compared to the Baltic countries, and the regions and countries have different histories. Accession to the European Union promoted intensification of grasslands but has also provided countries with financial support for conservation of low-input seminatural grasslands and wooded meadows.

Once essential to the food production of Northern Europe and the Baltic States, the value of seminatural grasslands to farm income nowadays is relatively low or non-existent for most farmers. The cost of fodder collection on these sites is viewed by many farmers as too costly for too little return. Hay collection on uneven surfaces is slower, fodder quality is more variable, and fencing more challenging compared to cultivated (intensified) grasslands. Thus, agricultural subsidies are important sources of income enabling farmers to manage semi-natural grasslands in the region. As a result, cultivated (intensified) grasslands, including grass leys in rotation, now by far exceed managed seminatural grasslands in the Nordic countries (Helgadottir et al. 2014) - and this process is continuing throughout the region (I. Herzon et al., unpubl. material).

\section{Ecology of the semi-natural grasslands of the region}

The activity of grazing and harvesting winter fodder and firewood changed the natural ecosystems and the species composition in them and created semi-natural vegetation types dominated by grasses and forbs. Many grassland plant species have clonal and horizontal growth (e.g. Knautia and Pllosella species), leaves placed near the ground (e.g. Primula, Pilosella and Leontodon species) or growth nodes located at the lower parts of the plants (e.g. grass species). Even if upper parts of the plants are removed, plants survive and continue growing. Some plants have properties that deter grazing mammals, such as spines (e.g. Rosa and Cirsium species). Removal of trees and shrubs, mowing and grazing result in increased light conditions and a changed microclimate. Grasslands are therefore also characterized by many small, drought-tolerant and light-demanding plants. Typical plants in grasslands tolerate disturbances and stress, but are rather poor competitors (Grime 2001). The majority of grassland organisms are adapted to relatively nutrient-poor conditions, under which the competitive strategy is ill-adapted. Also, trampling, grazing and mowing reduce the power of competitive plants. In nutrient-poor grasslands, mycorrhizae are common, in which the fungal partner secures plant nutrient uptake and co-existence (Dostálek et al. 2013).

Grazing and mowing increase the availability of gaps allowing seed germination and establishment. Grazing animals disperse seeds of many plant and animal species - for plants not the least because 
many grassland plants have seeds tolerating ingestion and gut passage or stick to fur and hoofs. Seeds are also dispersed via transported hay and mowing machines.

\section{Biodiversity: patterns and drivers}

Semi-natural grasslands are known to be very species rich compared to most other vegetation types in the Nordic-Baltic region (Kull and Zobel 1991; Austrheim et al. 1999; Eriksson et al. 2002). There are many plants, insects, fungi and birds that live in these open landscapes that are moderately affected by human activity (Artsdatabanken 2018).

At small spatial scales, Nordic-Baltic grasslands can be very rich in vascular plant species. Among the scale-dependent world records of vascular plant species richness in any habitat reported by Wilson et al. (2012), there are three entries from the study region: 12 species on $0.001 \mathrm{~m}^{2}$ in a limestone grassland on Öland, Sweden, as well as 25 and 42 species of a wooded meadow in western Estonia, on 0.01 and $0.04 \mathrm{~m}^{2}$, respectively (see Kull and Zobel 1991). However, for areas of $0.1 \mathrm{~m}^{2}$ and larger, mean and maximum richness values of vascular plants in the Nordic-Baltic region more and more lag behind similar grasslands in other regions of the Palaearctic biogeographic realm, such as Eastern Europe, Western Europe, Russia or the Mediterranean Region, the Middle East and the Caucasus (Dengler et al. 2020). For meso-xeric grasslands, the mean richness on $100 \mathrm{~m}^{2}$ in the Nordic-Baltic region is "only" about 40 species, while in Eastern Europe, the average is around 75 species (Dengler et al. 2020).

However, one peculiarity of the Nordic-Baltic grasslands is that bryophytes and lichens play a bigger role than in any other Palaearctic region studied (Dengler et al. 2020). This is true across grassland types, but it is particularly pronounced in rocky grasslands where terricolous bryophytes and lichens together on average contribute more species than vascular plants (Ejrnæs and Poulsen 2001; Boch and Dengler 2006; Löbel and Dengler 2008; Dengler et al. 2020). When considering also the bryophytes and lichens growing on other substrata than soil (e.g. saxicolous and epiphytic species), total species richness of the vegetation in rocky outcrop communities of Saaremaa, Estonia, can be as high as 140 species on $100 \mathrm{~m}^{2}$ (Dengler and Boch 2008). However, already when taking only terricolous species into account, the richness of bryophytes and lichens in the rocky grassland communities of the alvars of Öland (Sweden) and Saaremaa (Estonia) are higher for most of the analyzed grain sizes than in any other known Palaearctic grassland type (Dengler et al. 2020).

In a study of a wide range of dry grassland types in Southern Öland, Sweden, Löbel et al. (2006) found that among the studied environmental factors, soil $\mathrm{pH}$ was the most important for all three taxonomic groups in the vegetation: it had a positive effect on plot-scale species richness of bryophytes and lichens and a unimodal one on that of vascular plants. Other important factors were microrelief (positive for all taxa, vascular plants and bryophytes) and size of the dry grassland area (positive for all taxa, bryophytes and lichens). Across a wide range of Danish semi-natural grasslands from dry to wet, Moeslund et al. (2013) found that soil moisture (represented by the topographic wetness index) had a strong negative impact on plot-scale vascular plant species richness.

While in the study of Löbel et al. (2006), land use was no influential variable (probably because all the land uses occurring there were of low intensity), many other studies found pronounced effects of land use and land use history. Finnish cattle pastures were most diverse at plot scale when continuously grazed, intermediate when grazing had been restarted 3-8 years ago and lowest in pastures that were abandoned for more than 10 years (Pykälä 2004). The loss of species in Finnish grassland started almost immediately after abandonment, reached a plateau between year 15 and 40, followed by a second strong decrease afterwards (Pykälä et al. 2005). Swedish calcareous and 
coastal pastures at the $0.001-\mathrm{m}^{2}$ scale showed a humpbacked relationship to grazing intensity with the moderately grazed plots being richest and the heavily grazed and long abandoned ones being poorest (Dupré and Diekmann 2001). However, this effect vanished more and more towards larger plot sizes and was absent at $1000 \mathrm{~m}^{2}$, meaning that abandoned grasslands did not lose species at larger grain sizes, but just became more patchy, i.e. had higher beta-diversity (Dupré and Diekmann 2001). One must also consider that there can be a considerable time-lag in the extinction of species when environmental conditions become worse. Helm et al. (2006) demonstrated for alvar grasslands on Saaremaa and Muhu, Estonia, that the negative effects of grassland fragmentation became visible at the plot scale only with decades of delay ("extinction debt").

Semi-natural grasslands are structurally relative simple, but highly biodiverse ecosystems. Coexistence of many different species is governed by many ecological processes, including large mammal grazing, often replaced by extensive human use (e.g. mowing), which interacts with other biotic as well as abiotic factors. Resource limitation is a key factor in maintaining the high diversity and coexistence between plant species in semi-natural grasslands (Pykälä 2005).

\section{Threats}

Among the threat factors of grassland biodiversity, in the Nordic-Baltic region clearly those related to changes in grassland management prevail, in particular abandonment and general intensification, to a lesser extent also overgrazing of un-improved grasslands (Table 3 ). While natural grasslands lost only a small proportion of their original area to other land uses, secondary grasslands lost about $2 / 3$ compared to their maximum extent, which is the worst situation in all assessed regions of the Palaearctic biogeographic realm (Dengler et al. 2020). However, currently and in the near future further habitat losses due to land use conversions are of subordinate importance. Likewise, altered site conditions, climate change, invasive species and direct impacts of humans and their infrastructure have no or low impact. Only eutrophication is considered of medium importance (Table 3). For the majority of drivers no major change in severity is expected for the next decade, while for abandonment and climate change impacts, we predict an increase in severity (Table 3).

\section{$<$ Table 3 approximately here $>$}

The main threats to grassland ecosystems result from the lack of intact native grazer faunas and the changed agronomic frame around semi-natural grasslands as socio-ecological systems. Grasslands depend on grazing or similar disturbances. However, semi-natural grasslands have a much lower productivity than agriculturally improved grasslands (intensified grasslands in Table 1). Thus, they are the first ones that are either excluded from economic activity of farms by abandonment or intensified to increase their economic value (I. Herzon et al., unpubl. material). Accordingly, abandonment and underuse are amongst the most important drivers of biodiversity and habitat loss during recent decades (Raatikainen et al. 2007; Rūsina 2017; Lehtomaa et al. 2018; Dengler and Tischew 2018; Török et al. 2018; see Table 3). Abandonment results from changes in agricultural practices, namely the simplification of farm structure and farming systems. A similarly negative factor is agricultural intensification (Fig. 2b), namely high frequency of cutting, re-seeding, fertilizing and drainage (see Table 3 under "Other forms of intensification" and "Altered water regime"). Generally, intensification affects comparatively fertile grasslands on flat terrain, but abandonment is a bigger threat for dry and wet grasslands, which are located in difficult terrain with harder access for agricultural management. Ultimately, both drivers lead to habitat loss, which in turn results in high fragmentation levels - a threat of grassland maintenance and restoration of its own. The utmost limit of intensification is the conversion of permanent to temporary grasslands, which are reseeded regularly. It results not only in 
loss of biodiversity but also in decreased chances for restoration of semi-natural grasslands in the future as restoration in arable land is less successful due to high nutrient levels. A comparison of the Baltic States with three Nordic countries (Norway, Sweden, Finland) showed that the temporary grassland share was as high as $70-90 \%$ in Finland and Sweden, but less than $60 \%$ in the Baltic States and Norway (I. Herzon et al., unpubl. material). Conversion to arable land and afforestation (Fig. $2 \mathrm{~h}$ ) is also a common threat throughout the region (Table 3). In Norway, habitat loss due to the building of new homes, holiday houses in mountain regions, and roads threatens semi-natural grasslands. Specific threats to wooded pastures and meadows are imbalanced tree stand age structure that causes a lack of trees of certain age brackets, thus reducing the habitat conditions for long-term survival of tree-dependent species (Bergmeier et al. 2010).

Invasive species and climate change are reported as minor threats at present but with potential to increase in the near future (Table 3; see also Dengler and Tischew 2018; Török et al. 2018). Mostly species-poor grasslands, for instance semi-improved grasslands and grasslands with high disturbance levels, are prone to invasions. The tall forbs Solidago canadensis and S. gigantea as well as Impatiens glandulifera, Fallopia sachalinensis, F. japonica, in Latvia and Lithuania also Echinocystis lobata, Rumex confertus, Bunias orientalis, and the shrubs Amelanchier spicata and Rosa rugosa are currently the most widespread neophytes that tend to form dominant stands in former grasslands (Dengler and Tischew 2018; Gudžinskas et al. 2014). As a result of abandonment and euthrophication, native species such as Calamagrostis epigejos and Pteridum aquilinum are gaining ground, leading to species-poor mono-dominant stands (Dengler and Tischew 2018). Other winner species resulting from land-use change are Anthriscus sylvestris, Aegopodium podagraria, Arrhenatherum elatius, Chaerophyllum aromaticum, Galium aparine, Urtica dioica, Phragmites australis (in wet grasslands) and Deschampsia flexuosa (in dry sandy grasslands) (e.g. Rūsina 2017).

Continuous warming has been documented during spring and summer in the southern parts and during autumn and spring in the northern parts of the Baltic Sea basin (BACC II Author Team 2015). The duration of the cold season has decreased, duration of precipitation periods has increased and there is an increased risk of extreme precipitation events. For the Baltic States, there has been a significant increase in the number of hot days and nights and the number of heat waves, as well as a significant decrease in the number of frost days. Similar tendencies are projected also in the future (BACC II Author Team 2015). Widespread increase in atmospheric temperatures and moisture content seems to have rather positive direct effects on vascular plant species richness in grasslands of the region (Dengler and Tischew 2018). Increased plant species diversity at mountain tops (Kullman 2010) and alpine insect diversity as a response to glacier retreat (Franzén and Öckinger 2012) are reported. Still, the high-altitude fauna is expected to be out-competed when temperatures rise (Franzén and Öckinger 2012). Higher temperatures will promote northward and upward shifts in the boundaries of species occurrence, sometimes at the cost of the original species in that area. For instance, the range of Lolium perenne, which is a non-native species in the northern part of the region, will expand. It will change species composition, as it is a competitive species commonly dominating the sward of seminatural pastures in Central Europe (Höglind et al. 2013). Wet grasslands of the Northern Europe can experience negative impacts due to less ice and snow cover, leading in changing moisture regime during spring. Floodplain grasslands will experience less spring flooding (Apsìte et al. 2013), meaning also less possibilities for dispersal of grassland flora and fauna which is facilitated by floods. It could partly be mitigated by greater water availability as precipitation is forecasted to increase for Northern Europe, thus offering opportunities to restore or create new wet grasslands from intensively managed drained grasslands or croplands (Joyce et al. 2016). 
While the negative effects of eutrophication are considered overall as medium (Table 3 ), there are strong regional differences regarding the atmogenic nitrogen deposition, which for semi-natural grasslands usually is the main source of eutrophication. Denmark is highly affected, Lithuania moderately, Latvia and the southernmost parts of Norway and Sweden at a low level, while this driver is not relevant at all in the majority of the region (Sutton et al. 2011).

\section{Conservation and restoration}

As natural and semi-natural grasslands are highly important for biodiversity conservation in the region, while at the same time many of their types are threatened (Janssen et al. 2016; see Table 2), various grassland types are protected nationally in the countries of the region. Moreover, the European Union, via its Habitats Directive (European Union 2013), protects 24 grassland types of the region as of "community importance" (Table 2). Of these, nine are priority habitats, subject to a particular strict protection and monitoring across the countries: "Boreal Baltic coastal meadows" (Habitat type 1630 in Table 2), "Fixed coastal dunes with herbaceous vegetation (grey dunes)" (2130), xeric sand calcareous grasslands (6120), important orchid sites among the "Seminatural dry grasslands and scrubland facies on calcareous substrates (Festuco-Brometalia)" (6210), "Species-rich Nardus grasslands, on siliceous substrates in mountain areas (and submountain areas, in Continental Europe)" (6230), "Fennoscandian lowland species-rich dry to mesic grasslands" (6270), "Nordic alvar and precambrian calcareous flatrocks" (6280), "Fennoscandian wooded meadows" (6530) and "Limestone pavements" (8240).

Semi-natural grasslands and wooded meadows are maintained through appropriate grazing and haying pressure. Clearing of scrub is an essential practice for restoration and for management in areas where grazing pressure is insufficient. In the case of seashore meadows, clearing of reeds at the shoreline is frequently necessary for meadow restoration and may be needed periodically even in grazed seashore meadows. Substantial tree felling and clearing of shrubs, such as Juniperus communis, is necessary for restoration of afforested and abandoned sites, respectively. As a way of combating abandonment of grasslands, alternative management strategies and uses for biomass beyond fodder have been explored. Since 2010, Estonia has used hay and reed biomass from the extensive semi-natural grasslands of Matsalu National Park to heat the Lihula District, an area of 384 $\mathrm{km}^{2}$ (Kask 2014).

The European Union supports semi-natural grasslands through agri-environment-climate schemes for management and non-productive investment to improve the condition of semi-natural grasslands. Each member country applies these mechanisms, along with own country funds and programs, to support grasslands conservation and restoration according to their agriculture programs and biodiversity strategies. Additionally, there are specific schemes to support cultivated (intensified) grasslands. Payment amounts, requirements for management and minimum area and type of grassland included in schemes vary across the countries.

The main principles of management for the semi-natural grasslands is no external inputs and sufficient grazing pressure or other management to retain the characteristics that define the habitat type. Development and implementation of site-specific management plans are increasingly being recognized as important parts of sustainable conservation of semi-natural grasslands but are not yet universally practiced. In Finland, for example, site-specific management plans are a requirement for farmers or landowners to receive the agri-environment-climate measure for semi-natural grasslands. Latvia began training farmers in making management plans for their grasslands in 2016. Agrienvironment-climate schemes are primarily actions-based, while schemes based on management 
outcomes, such as those reported from Baden-Württemberg, Germany (Russi et al. 2016), and the Burren, Ireland (Dunford 2016) are mainly lacking (Herzon et al. 2018), although Finland has a twotier payment system, with the higher payment reserved for sites deemed nationally or regionally valuable. Countries use obligatory annual management practices and management diaries, along with inspections, as a way to assure that management is carried out. An outcome of support payments being action rather than results-based is that remedial actions such as ploughing to combat invasive species and reseeding are generally proscribed in the schemes.

Land use history affects the biodiversity of sites and their restoration potential, and research supports that grasslands (semi-natural pastures and meadows) have a measurable positive effect on biodiversity compared to other farmland land-use types (Santangeli et al. 2019). The most valuable semi-natural grasslands have been under continuous management for hundreds of years, but these are increasingly rare. Commitment to management and restoration varies across the Nordic-Baltic region. Estonia has implemented a large-scale restoration of its seashore meadows and alvars and revitalized associated grazing in recent years (https://life.envir.ee/english-project-life-alvars; Kasari et al. 2018). The primary concern for semi-natural grasslands in Latvia is finding ways to make the lowinput hay-making and pasturing viable for farmers. Finland recognizes the dire state of its seminatural grasslands and grazed forests, collectively known as traditional rural biotopes, as the country's most threatened habitat type but has been unsuccessful in increasing the overall area under management (Lehtomaa et al. 2018). In Norway, semi-natural mown grasslands (hay meadows) are critically threatened (CR, Artsdatabanken 2018), and are a "selected habitat type" according to the Norwegian Act on Natural Diversity. Since 2009, Norway has run an Action Plan for Hay Meadows (Direktoratet for naturforvaltning 2009), through which it has organized management of approximately 700 hay meadows. Financial support is provided to landowners and farmers who carry out management of the hay meadows according to a plan made by biologists (Miljødirektoratet 2016).

Fodder potential of the semi-natural grasslands is largely determined by the northern conditions and the variation in fodder quality and quantity according to habitat type. In the cases of seashore meadows and other lush grasslands, grazing, which should start as soon in the season as possible, is often delayed by the wet spring, which can result in decreased palatability of plants and decreased grazing when the animals are eventually turned out to pasture. Dry summers with extreme drought events will be more pronounced in southern part of the region (BACC II Author Team 2015), and may also negatively affect fodder quality and regrowth. Along the Baltic Sea coast, occurrence of bluegreen algae may result in animals having to be removed from the coastal meadows altogether because the grazing animals cannot drink the contaminated water.

\section{Acknowledgements}

We are grateful to Iwona Dembicz (University of Warsaw and Zurich University of Applied Sciences) for providing nice photos from various locations in the study region.

\section{References}

Andersen, S. T. (1965). Interglacialer og interstadialer i Danmarks kvartær. Meddelelser fra Dansk Geologisk Forening 15, 486-506.

Apals, J., Atgāzis, M., Daiga, J., et al. (1974). Latvijas PSR arheoloǵija [Archaeology of Latvian SSR]. Rīga: Latvijas PSR Zinātṇu akadēmija.

Artsdatabanken (2018). Norsk rødliste for naturtyper 2018. URL: https://www.artsdatabanken.no/rodlistefornaturtyper.

Apsīte, E., Rudlapa, I., Latkovska, I. and Elferts, D. (2013). Changes in Latvia river discharge regime at the turn of the century. Hydrology Research 44, 554-569. 
Auffret, A. G. and Cousins, S. A. O. (2018). Land uplift creates important meadow habitat and a potential original niche for grassland species. Proceedings of the Royal Society, B, 285, Article 20172349.

Austrheim, G., Olsson, G. and Grøntvedt, E. (1999). Land-use impact on plant communities in semi-natural sub-alpine grasslands of Budalen, central Norway. Biological Conservation, 87, 369-379.

BACC II Author Team (2015). Second assessment of climate change for the Baltic Sea basin. London: Springer.

Barnosky, A. D., Koch, P. L., Feranec, R. S., Wing, S. L. and Shabel, A. B. (2004). Assessing the causes of Late Pleistocene extinctions on the continents. Science 306, 70-75.

Berglund, B. E., Kitagawa, J., Lagerås, P., et al. (2014). Traditional farming landscapes for sustainable living in Scandinavia and Japan: Global revival through the Satoyama Initiative. Ambio, 43, 559-578.

Bergmeier, E., Petermann, J. and Schröder, E. 2010. Geobotanical survey of wood-pasture habitats in Europe: diversity, threats and conservation. Biodiversity and Conservation 19, 2995-3014.

Björck, S., Noe-Nygaard, N., Wolin, J., et al. (2000). Eemian Lake development, hydrology and climate: a multi-stratigraphic study of the Hollerup site in Denmark. Quaternary Science Reviews 19, 509-536.

Boch, S. and Dengler, J. (2006). Floristische und ökologische Charakterisierung sowie Phytodiversität der Trockenrasen auf der Insel Saaremaa (Estland). Arbeiten aus dem Institut für Landschaftsökologie Münster 15, 55-71.

Boch, S., Biurrun, I. and Rodwell, J. (2020). Grasslands of Western Europe. In: DellaSala, D. A. and Goldstein, M. I. (eds.) The encyclopedia of the world's biomes. Oxford: Academic Press - Elsevier.

Dunford, B. 2016. The Burren Life Programme: An overview [NESC Research Series Paper no. 9]. URL: http:// burrenprogramme.com/wp-content/uploads/2019/10/NESC-Research_Series_Paper_9_BDunford_Burren.pdf.

Dahl, E. (1998). The phytogeography of northern Europe: British Isles, Fennoscandia and adjacent areas. Cambridge: Cambridge University Press.

Dengler, J. (2003). Entwicklung und Bewertung neuer Ansätze in der Pflanzensoziologie unter besonderer Berücksichtigung der Vegetationsklassifikation. Archiv naturwissenschaftlicher Dissertationen 14, 1-297.

Dengler, J. and Boch, S. (2008). Sampling-design effects on properties of species-area curves - A case study from Estonian dry grassland communities. Folia Geobotanica 43, 289-304.

Dengler, J. and Tischew, S. (2018). Grasslands of Western and Northern Europe - between intensification and abandonment. In Squires, V. R., Dengler, J., Feng, H. and Hua, L. (eds.) Grasslands of the world: diversity, management and conservation, pp. 27-63. Boca Raton: CRC Press.

Dengler, J., Löbel, S. and Boch, S. (2006). Dry grassland communities of shallow, skeletal soils (Sedo-Scleranthenea) in northern Europe. Tuexenia 26, 159-190.

Dengler, J., Biurrun, I., Boch, S., Dembicz, I. and Török, P. (2020). Grasslands of the Palaearctic biogeographic realm: introduction and synthesis. In: DellaSala, D. A. and Goldstein, M. I. (eds.) The encyclopedia of the world's biomes. Oxford: Academic Press - Elsevier.

Direktoratet for naturforvaltning (2009). Handlingsplan for slåttemark. Handlingsplaner for trua arter og naturtyper i Norge. Trondheim: Direktoratet for naturforvaltning.

Dostálek, T., Pánková, H., Münzbergová, Z. and Rydlová, J. (2013). The effect of AMF suppression on plant species composition in a nutrient-poor dry grassland. PLoS One 8, Article e80535.

Dupré, C. and Diekmann, M. 2001. Differences in species richness and life-history traits between grazed and abandoned grasslands in southern Sweden. Ecography 24, 275-286.

Eilart, J. (1975). Materials on the plant geographical division of the Baltic Republics. In: Laasimer, L. (ed.) Some aspects of botanical research in the Estonian SSR, pp 54-61. Tartu: Academy of Sciences of the Estonian SSR.

Ejrnæs, R. and Poulsen, R. S. (2001). Cryptogam-environment relationships in Danish grasslands. Lindbergia 26, 121-128.

Emanuelsson, U. (2009). The rural landscapes of Europe - How man has shaped European nature. Stockholm: Forskningsrådet Formas

Eriksson, O., Cousins, S. and Bruun, H. H. (2002). Land-use history and fragmentation of traditionally managed grasslands in Scandinavia. Journal of Vegetation Science 13, 743-748.

European Commission (ed.) (2013). Interpretation manual of European Union habitats - EUR 28. Brussels: DG Environment, European Commission.

FAO [Food and Agriculture Organization of the United Nations] (2019). FAOSTAT: Land cover. URL: http://www.fao.org/ faostat/en/\#data/LC [accessed on 7 October 2019].

Finnie, T. J. R., Preston, C. D., Hill, M. O., Uotila, P. and Crawley M. J. (2007). Floristic elements in European vascular plants: an analysis based on Atlas Florae Europaeae. Journal of Biogeography 34, 1848-1872

Franzén, M. and Öckinger, E. (2012). Climate-driven changes in pollinator assemblages during the last 60 years in an Arctic mountain region in Northern Scandinavia. Journal of Insect Conservation 16, 227-238.

Grime, J. P. (2001). Plant strategies, vegetation processes, and ecosystem properties. 2nd ed. Chichester: Wiley.

Gudžinskas, Z., Kaslauskas, M., Pilāte, D., et al. 2014. Lietuva sun Latvijas pierobežas invazĩvie organismi [Invasive organisms of Lithuanian and Latvian borderland]. Vilnius: BMK Leydikla.

Gustina, L., (2016). Zālāju apsaimniekošanas vēsture Latvijā [History of grassland management in Latvia]. Latvijas Veǵetācija 25, 65-79.

Hejcman, M., Hejcmanová, P., Pavlů, V. and Beneš, J. (2013). Origin and history of grasslands in Central Europe - a review. Grass and Forage Science 68, 345-363.

Helgadóttir, Á., Frankow-Lindberg, B. E., Seppänen, M. M., Søegaard, K. and Østrem, L. (2014). European grasslands overview: Nordic region. Grassland Science in Europe 19, 15-28. 
Helm, A., Hanski, I. and Pärtel, M. (2006). Slow response of plant species richness to habitat loss and fragmentation. Ecology Letters 9, 72-77.

Herzon I., Birge, T., Allen B., et al. (2018). Time to look for evidence: results-based approach to conservation on farmland in Europe. Land Use Policy 71, 347-354.

Hjelle, K.L., Halvorsen, L.S., Prøsch-Danielsen, L., et al. (2018). Long-term changes in regional vegetation cover along the west coast of southern Norway: The importance of human impact. Journal of Vegetation Science 29, 404-415.

Höglind, M., Thorsen, S. M. and Semenov, M. A. (2013). Assessing uncertainties in impact of climate change on grass production in Northern Europe using ensembles of global climate models. Agricultural and Forest Meteorology 170, 103-113.

Holm, S. R. and Svenning, J.-C. (2014). 180,000 years of climate change in Europe: Avifaunal responses and vegetation implications. PLOS ONE 9, Article e94021.

Iversen, J. (1973). The development of Denmark's nature since the last glacial. Copenhagen: C. A. Reitzels Forlag.

Janssen, J. A. M., Rodwell, J. S., Garcia Criado, M., et al. (2016). European Red List of Habitats - Part 2. Terrestrial and freshwater habitats. Luxembourg: European Union.

Jones, R. J. A., Houškova, B., Bullock, P. and Montanarella, L. (eds.) (2005). Soil resources of Europe (2nd ed.). Luxembourg: Office for Official Publications of the European Communities.

Jonsell, B. and Karlsson, T. (2004). Endemic vascular plants in Norden. In Jonsell, B. (ed.) Flora Nordica-General Volume, pp 139-159. Stockholm: Royal Swedish Academy of Sciences.

Joyce, C. B., M. Simpson, and M. Casanova. 2016. Future wet grasslands: ecological implications of climate change. Ecosystem Health and Sustainability 2, Article e01240.

Kabucis, I. (ed.) (2001). Latvijas biotopi. Klasifikators [Habitats of Latvia. Classifier]. Rīga: Latvijas Dabas fonds.

Kasari, L., Esko, A., Prangel, E., Hernandez-Agramonte, I. M. and Helm, A. (2018). Large-scale grassland restoration in Estonia: best practice and socio-economic implications. URL: https://peerageofscience.org/conference/ eccb2018/107825/

Kask, L. (2014). Energy production from biomass of Matsalu Natural Park, Estonia. URL: http:// grassservice.balticgrasslands.eu/content/uploads/2014/10/12_Maatsalu-nature-park_L.Kask_1.pdf.

Kontula, T. and Raunio, A. (2018). Liite 1. Luontotyyppinimien käännökset, Suomen luontotyppien uhanalaisuus 2018 Luontotyyppien punainen kirja, Osa II [Annex 1 of Translations of habitat types, threatened habitat types in Finland: Red List of Habitats 2018, Part II: Descriptions of habitat types]. Helsinki: Finnish Environment Institute and Ministry of the Environment.

Kull, K. and Zobel, M. (1991). High species richness in an Estonian wooded meadow. Journal of Vegetation Science 2, 711714.

Kullman, L. (2010). Alpine flora dynamics - a critical review of responses to climate change in the Swedish Scandes since the early 1950s. Nordic Journal of Botany 28, 398-408.

Kuneš, P., Svobodová-Svitavská, H., Kolář, J., et al. (2015). The origin of grasslands in the temperate forest zone of eastcentral Europe: long-term legacy of climate and human impact. Quaternary Science Reviews 116, 15-27.

Kuosmanen, N., Marquer, L., Tallavaara, M., et al. (2018). The role of climate, forest fires and human population size in Holocene vegetation dynamics in Fennoscandia. Journal of Vegetation Science 29, 382-392.

Lawesson, J.E., Skov, F. The phytogeography of Denmark revisited. Plant Ecology 158, 113-122.

Lehtomaa, L., Ahonen, I., Hakamäki, H., et al. (2018). Perinnebiotoopit [Semi-natural grasslands and grazed woodlands]. In Kontula, T. and Raunio, A. (eds.) Suomen luontotyppien uhanalaisuus 2018 Luontotyyppien punainen kirja [Threatened habitat types in Finland: Red List of Habitats 2018, Part II: Descriptions of habitat types], pp 661-757. Helsinki: Finnish Environment Institute and Ministry of the Environment.

Löbel, S. and Dengler, J. (2008) [“2007”]. Dry grassland communities on southern Öland: phytosociology, ecology, and diversity. Acta Phytogeographica Suecica 88, 13-31.

Löbel, S., Dengler, J. and Hobohm, C. (2006). Species richness of vascular plants, bryophytes and lichens in dry grasslands: The effects of environment, landscape structure and competition. Folia Geobotanica 41, 377-393.

Marquer, L., Gaillard, M.-J., Sugita, S., et al. (2014). Holocene changes in vegetation composition in northern Europe: why quantitative pollen-based vegetation reconstructions matter. Quaternary Science Reviews 90, 199-216.

Miljødirektoratet (2016). "Slå et slag for slåttemarka" [Brosjyre M-566]. URL: http://www.miljodirektoratet.no.

Moeslund, J. E., Arge, L., Bøcher, P. K., et al. (2013). Topographically controlled soil moisture drives plant diversity patterns within grasslands. Biodiversity and Conservation 22, 2151-2166.

Mucina, L., Bültmann, H., Dierßen, K., et al. (2016). Vegetation of Europe: Hierarchical floristic classification system of vascular plant, bryophyte, lichen, and algal communities. Applied Vegetation Science, Supplement, 19, 3-264.

Nielsen, A. B., Giesecke, T., Theuerkauf, M., et al. (2012). Quantitative reconstructions of changes in regional openness in north-central Europe reveal new insights into old questions. Quaternary Science Reviews 47, 131-149.

Paal, J. (1997). Eesti taimkatte kasvukohatüüpide klassifikatsioon [Classification of Estonian vegetation site types]. Tallinn: Eesti Keskkonnaministeerium \& ÜRO Keskonnaprogramm.

Pärtel, M., Bruun, H. H. and Sammul, M. (2005). Biodiversity in temperate European grasslands: origin and conservation. In Lillak, R., Viiralt, R., Linke, A. and Geherman, V. (eds.) 13th International Occasional Symposium of the European Grassland Federation, pp 1-14. Tartu: European Grassland Federation.

Patton, H., Hubbard, A., Andreassen, K., et al. (2017). Deglaciation of the Eurasian ice sheet complex. Quaternary Science Reviews 169, 148-172. 
Pedersen, E. A. and Widgren, M. (2011). Agriculture in Sweden 800 BC - AD 1000. In Myrdal, J. and Morell, M. (eds.) The agrarian history of Sweden. From 4000 BC to AD 2000, pp 46-72. Lund: Nordic Academic Press.

Peel, M. C., Finlayson, B. L. and McMahon, T. A. (2007). Updated world map of the Köppen-Geiger climate classification. Hydrology and Earth System Sciences 11, 1633-1644.

Piličauskas, G., Asheichyk, V., Osipowicz, G., et al. 2018. The Corded Ware culture in the Eastern Baltic: New evidence on chronology, diet, beaker, bone and flint tool function. Journal of Archaeological Science 21, 538-552.

Pott, R. (1995). The origin of grassland species and grassland communities in Central Europe. Fitosociologia 29, 7-32.

Pykälä, J. (2001). Perinteinen karjatalous luonnon monimuotoisuuden ylläpitäjänä [Traditional animal husbandry as an agent of biodiversity maintenance]. Helsinki: Finnish Environment Institute.

Pykälä, J. (2004). Cattle grazing increases plant species richness of most species trait groups in mesic semi-natural grasslands. Plant Ecology 175, 217-226.

Pykälä, J. (2005). Plant species responses to cattle grazing in mesic semi-natural grassland. Agriculture, Ecosystems and Environment 108, 109-117

Pykälä, J., Luoto, M., Heikkinen, R. K. and Kontula, T. (2005). Plant species richness and persistence of rare plants in abandoned semi-natural grasslands in northern Europe. Basic and Applied Ecology 6, 25-33.

Raatikainen, K. M., Heikkinen, R. K. and Pykälä, J. 2007. Impacts of local and regional factors on vegetation of boreal seminatural grasslands. Plant Ecology 189, 155-173.

Rašomavičius ,V. (ed.) (1998). Lietuvos augalija. Pievos [Vegetation of Lithuania. Grasslands]. Kaunas: Leidykla Šviesa.

Reimann, C., Siewers, U., Tarvainen, T., et al. 2003. Agricultural soils of Northern Europe. A geochemical atlas. Geologisches Jahrbuch, Reihe D, Sonderheft, 5, 1-279.

Reinton, L. (1955). Sæterbruket i Noreg. Bind 1. Sætertypar og driftsformer. Oslo: Aschehoug.

Rūsina, S. (2007). Latvijas mezofito un kserofito zālāju daudzveidība un kontaktsabiedrības. [Diversity and contact communities of mesophytic and xerophytic grasslands in Latvia]. Latvijas Veǵetācija 12,1-366.

Rūsina, S. (ed.) (2017). Protected habitat conservation guidelines in Latvia 3: Semi-natural grasslands. Sigulda: Nature Conservation Agency.

Russi, D., Margue, H., Oppermann, R., Keenleyside, C., 2016. Result-based agri-environment measures: market-based instruments, incentives or rewards? The case of Baden Württemberg. Land Use Policy 54, 69-77

Sammul, M., Kull, K. and Kukk, T., (2000). Natural grasslands in Estonia: evolution, environment and economic roles. In: Viiralt, R., Lillak, R. and Michelson, M. (eds.) Conventional and ecological grassland management. Comparative research and development. Proceedings of the International Symposium, Tartu July 4-6, 2000. pp. 20-26. Tartu: Estonian Agricultural University \& Estonian Grassland Society.

Sandom, C. J., Ejrnæs, R., Hansen, M. D. D. and Svenning, J.-C. (2014). High herbivore density associated with vegetation diversity in interglacial ecosystems. Proceedings of the National Academy of Sciences of the United States of America, 111, 4162-4167.

Santangeli, A., Leikoinen, A., Lindholm, T. and Herzon, I. (2019). Organic animal farms increase farmland bird abundance in the Boreal region. PLOS ONE 14, Article e0216009.

Schaminée, J.H.J., Chytrý, M., Dengler, J., et al. (2016). Development of distribution maps of grassland habitats of EUNIS habitat classification. Copenhagen: European Environment Agency.

Schweiger, A. H. and Svenning, J.-C. (2018). Down-sizing of dung beetle assemblages over the last 53000 years is consistent with a dominant effect of megafauna losses. Oikos 127, 1243-1250.

Sommer, R. S., Benecke, N., Lõugas, L., Nelle, O. and Schmölcke, U. (2011). Holocene survival of the wild horse in Europe: a matter of open landscape? Journal of Quaternary Science 26, 805-812.

Squires, V. R., Dengler, J., Feng, H. and Hua, L. (eds.) (2018). Grasslands of the world: diversity, management and conservation. Boca Raton: CRC Press.

Sutton, M. A., Howard, C. M., Erisman, J. W., et al. (eds.) (2011). The European nitrogen assessment: sources, effects and policy perspectives. Cambridge: Cambridge University Press.

Svenning, J.-C. (2002). A review of natural vegetation openness in north-western Europe. Biological Conservation 104, 133148.

Theuerkauf, M., Bos, J. A. A., Jahns, S., et al. (2014). Corylus expansion and persistent openness in the early Holocene vegetation of northern central Europe. Quaternary Science Reviews 90, 183-198.

Tishkov, A., Belonovskaya, E., Smelansky, I.E., et al. (2020). Temperate grasslands and shrublands of Russia. In: DellaSala, D. A. and Goldstein, M. I. (eds.) The encyclopedia of the world's biomes. Oxford: Academic Press - Elsevier.

Török, P., Janišová, M., Kuzemko, A., Rūsiṇa, S. and Dajić Stevanović, Z. (2018). Grasslands, their threats and management in Eastern Europe. In Squires, V. R., Dengler, J., Feng, H. and Hua, L. (eds.) Grasslands of the world: diversity, management and conservation, pp. 64-88. Boca Raton: CRC Press.

Tóth, G., Montanarella, L., Solbovoy, V., et al. 2008. Soils of the European Union. Luxembourg: European Commission.

Walter, H. and Breckle, S.-W. (1986). Ecological systems of the geobiosphere. Berlin: Springer.

Wilson, J. B., Peet, R. K., Dengler, J. and Pärtel, M. 2012. Plant species richness: the world records. Journal of Vegetation Science 23, 796-802.

Zobel, M. and Kont, A. (1992). Formation and succession of alvar communities in the Baltic land uplift area. Nordic Journal of Botany 12, 249-256. 


\section{Figures and Tables}
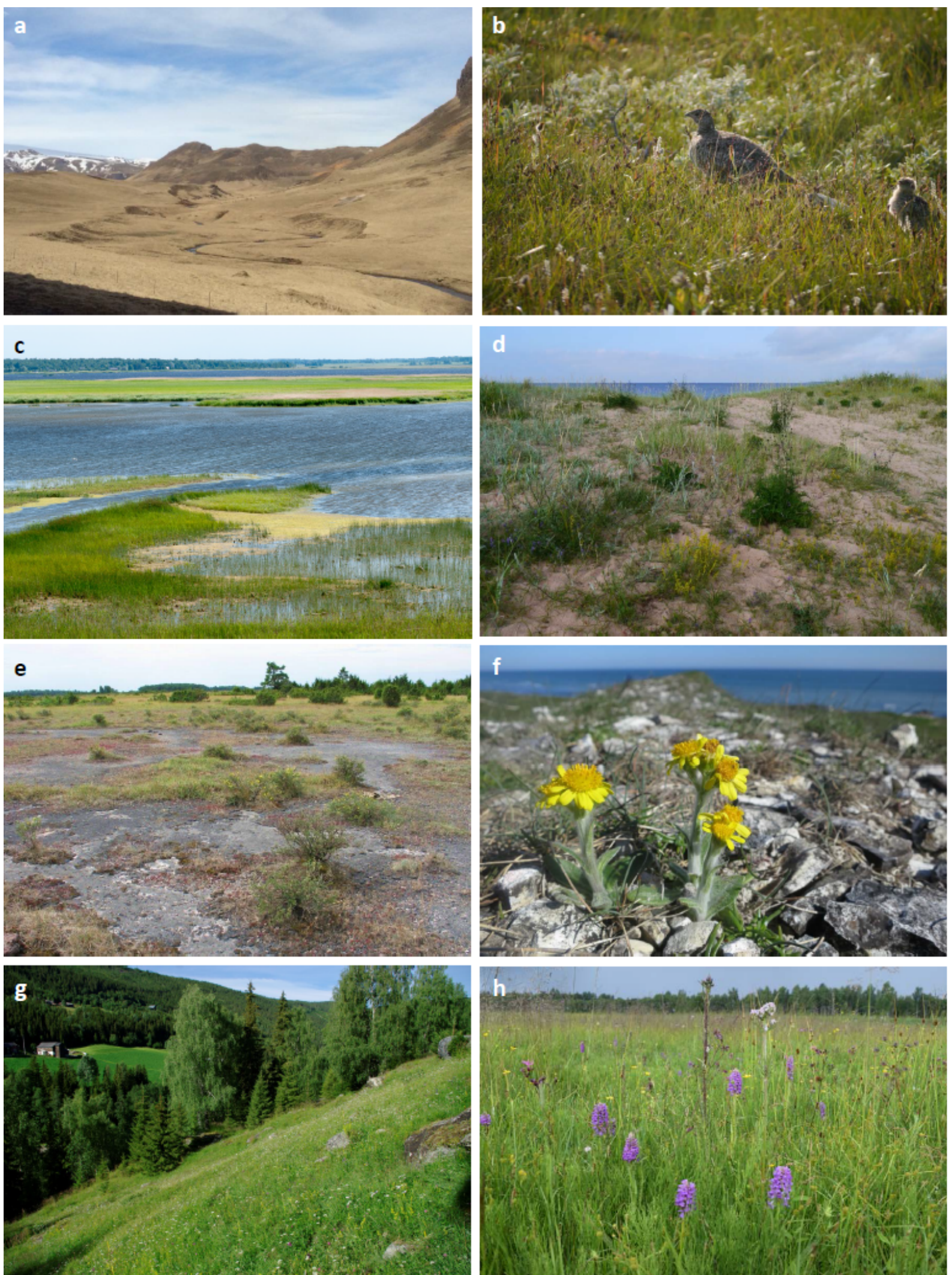

Fig. 1. Different grassland types in the Nordic-Baltic region: (a) natural arctic-alpine grassland in Iceland (Photo: T. Birge); (b) natural arctic-alpine grassland (habitat type E4.3b in Table 2) in Norway with willow ptarmigan (Lagopus lagopus) as a typical bird species (Photo: I. Dembicz), (c) coastal salt marsh (A2.5b) as a natural azonal grassland in Western Estonia (Photo: J. Dengler); coastal dune 
grassland (B1.4a) as a natural azonal grassland on Saaremaa, Estonia (Photo: I. Dembicz); (e) alvar vegetation on Southern Öland, Sweden - alvars are calcareous flatrocks with a mixture of natural vegetation on rocky outcrops (E1.1d) in the foreground, semi-natural meso-xeric grasslands on deeper soils (E1.2a) in the background, fens and shrublands; sometimes alvars are considered as extrazonal occurrences of the forest-steppe zonoecotone (Photo: I. Dembicz); (f) secondary, seminatural, meso-xeric grassland (E1.2a) on a coastal limestone cliff (B3.4a) in NW Jutland, Denmark, with the rare plant species Tephroseris integrifolia (Photo: H. H. Bruun); (g) secondary, semi-natural mesic grasslands (E2.1a or E2.2) in Norway (Photo: H. Sickel); (h) secondary, semi-natural, wet grassland (E3.4) in Latvia (Photo: S. Rūsiṇa). 

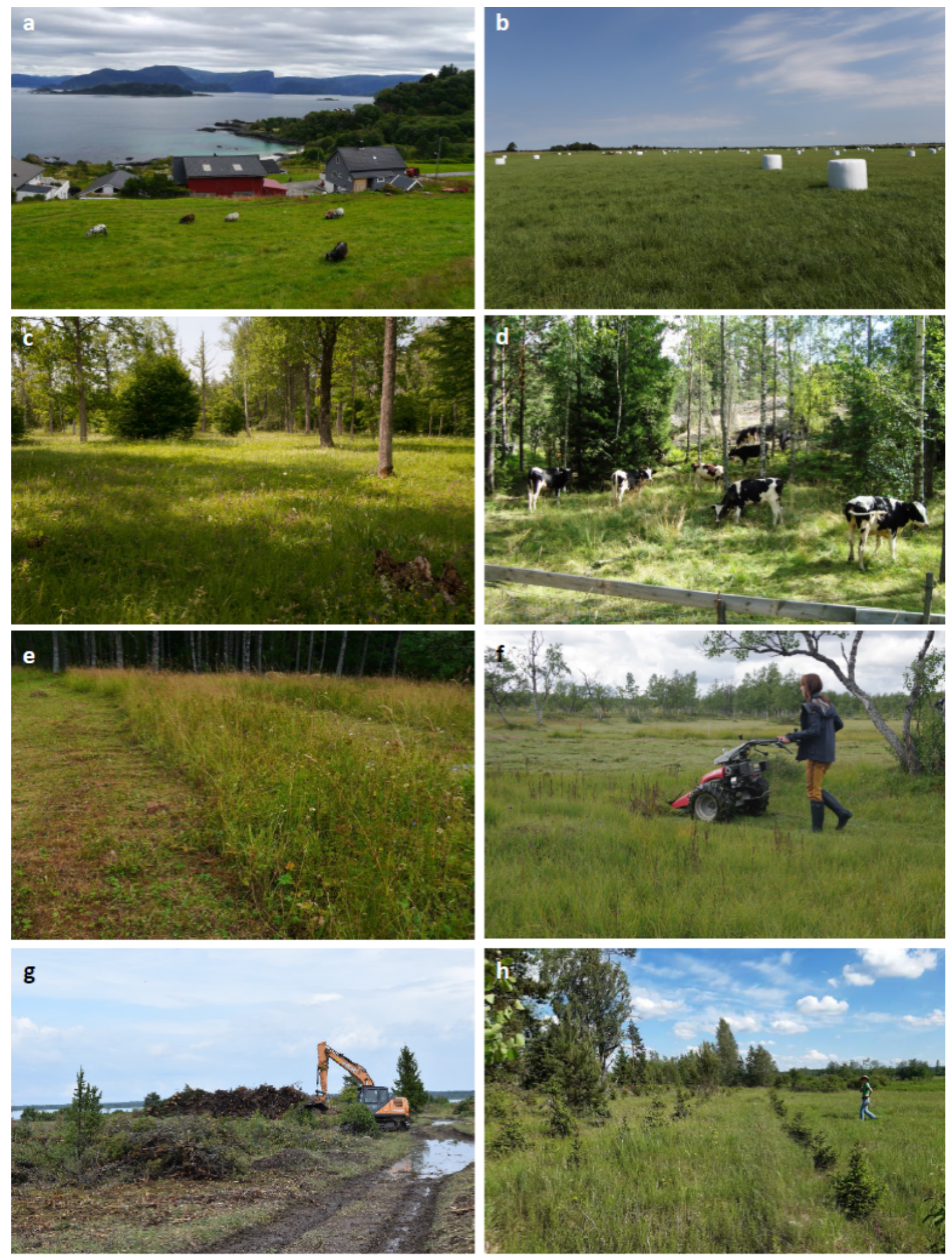

Fig. 2. Management, threats, conservation and restoration of Nordic-Baltic grasslands: (a) traditional sheep grazing on secondary, semi-natural mesic grassland (habitat type E2.1a in Table 2) on Vågs $\varnothing \mathrm{y}$ island, Norway (Photo: I. Dembicz); (b) Species-poor, secondary, strongly intensified mesic grassland in Lithuania (Photo: V. Rašomavičius); (c) the famous wooded meadow (E7.2) of Laelatu, Western Estonia, which holds two small scale species-richness world records (Kull and Zobel 1991; Wilson et al. 2012); (d) wooded pasture (E7.2), grazed by dairy cattle in Finland (Photo: T. Birge); (e) 
conservation management of semi-natural, mesic grasslands (E.2.2) in the Koli National Park, Finland - to support insects, strips of grasslands remained unmown (Photo. I. Dembicz); (f) machinery used to mimic traditional haymaking management on a semi-natural grassland of high conservation value in Norway (Photo: H. Sickel); (g) restoration of an alvar site in Western Estonia through removal of woody (Juniperus and Pinus) encroachment; ( $h$ ) afforestation (here with spruce) is one of the threats low-productive grasslands (here an acidic semi-natural grassland with Nardus stricta; E1.7) are subject to (Latvia; photo: S. Rūsina). 
Table 1. Overview of the region covered in this chapter with its eight political entities, their area and population, grassland area and grassland types. The categorization of grasslands follows the definitions in the "synthesis" chapter by Dengler et al. (2020). The values are rounded expert estimates, only partly supported by hard GIS data. HNV = high nature value; NA = not available.

\begin{tabular}{|c|c|c|c|c|c|c|c|c|c|c|}
\hline Region & $\begin{array}{c}\text { Denm } \\
\text { ark }^{1}\end{array}$ & $\begin{array}{l}\text { Faroe } \\
\text { Island } \\
\mathbf{s}^{2}\end{array}$ & $\begin{array}{l}\text { Icelan } \\
d^{2}\end{array}$ & $\begin{array}{c}\text { Norw } \\
\text { ay } \\
\text { (inclu } \\
\text { ding } \\
\text { Svalb } \\
\text { ard } \\
\text { and } \\
\text { Jan } \\
\text { Maye } \\
\text { n) }\end{array}$ & $\begin{array}{l}\text { Swed } \\
\text { en }\end{array}$ & $\begin{array}{c}\text { Finlan } \\
d^{4}\end{array}$ & $\begin{array}{l}\text { Eston } \\
\text { ia }^{5}\end{array}$ & $\begin{array}{l}\text { Latvia } \\
6\end{array}$ & $\begin{array}{l}\text { Lithua } \\
\text { nia }^{7}\end{array}$ & Total \\
\hline Total area included $\left[\mathrm{km}^{2}\right]$ & $\begin{array}{r}43,07 \\
5\end{array}$ & 1,399 & $\begin{array}{r}102,8 \\
20\end{array}$ & $\begin{array}{r}385,1 \\
55\end{array}$ & $\begin{array}{r}440,9 \\
40\end{array}$ & $\begin{array}{r}337,0 \\
30\end{array}$ & $\begin{array}{r}45,10 \\
0\end{array}$ & $\begin{array}{r}63,70 \\
0\end{array}$ & $\begin{array}{r}65,20 \\
0\end{array}$ & $\begin{array}{r}1,484 \\
419\end{array}$ \\
\hline Number of inhabitants & $\begin{array}{r}5,814 \\
000\end{array}$ & $\begin{array}{r}52,00 \\
0\end{array}$ & $\begin{array}{r}360,0 \\
00\end{array}$ & $\begin{array}{r}5,328 \\
000\end{array}$ & $\begin{array}{l}10,29 \\
1,000\end{array}$ & $\begin{array}{r}5,521 \\
000\end{array}$ & $\begin{array}{r}1,325 \\
000\end{array}$ & $\begin{array}{r}1,920 \\
000\end{array}$ & $\begin{array}{r}2,794 \\
000\end{array}$ & $\begin{array}{l}33,40 \\
5,000\end{array}$ \\
\hline $\begin{array}{l}\text { Population density [inhabitants / } \\
\mathbf{k m}^{2} \text { ] }\end{array}$ & 135.0 & 37.2 & 3.5 & 13.8 & 23.3 & 16.4 & 29.4 & 30.1 & 42.9 & 22.5 \\
\hline Total extant grasslands $\left[\mathrm{km}^{2}\right]$ & 1,750 & 1,000 & $\begin{array}{r}35,65 \\
0\end{array}$ & $\begin{array}{r}19,90 \\
0\end{array}$ & $\begin{array}{r}21,85 \\
0\end{array}$ & 2,900 & 2,950 & 8,700 & 8,300 & $\begin{array}{r}103,0 \\
00\end{array}$ \\
\hline - Fraction of territory & $4 \%$ & $71 \%$ & $35 \%$ & $5 \%$ & $5 \%$ & $1 \%$ & $7 \%$ & $14 \%$ & $13 \%$ & $7 \%$ \\
\hline - Proportion of natural grasslands & $29 \%$ & $50 \%$ & $87 \%$ & $65 \%$ & $23 \%$ & $9 \%$ & $5 \%$ & $<1 \%$ & $1 \%$ & $49 \%$ \\
\hline - Proportion of HNV grasslandsa & $46 \%$ & NA & NA & NA & NA & NA & $44 \%$ & NA & NA & $\begin{aligned} & \text { ca. } \\
& 45 \%\end{aligned}$ \\
\hline $\begin{array}{l}\text { (1) Natural grasslands (extant) } \\
{\left[\mathrm{km}^{2}\right]}\end{array}$ & 500 & 500 & $\begin{array}{r}31,00 \\
0\end{array}$ & $\begin{array}{r}12,95 \\
0\end{array}$ & 5,000 & 250 & 150 & 50 & 100 & $\begin{array}{r}50,50 \\
0\end{array}$ \\
\hline - as fraction of their original area & $20 \%$ & $95 \%$ & $95 \%$ & $90 \%$ & $90 \%$ & $60 \%$ & $75 \%$ & NA & $75 \%$ & $\begin{array}{r}\text { ca. } \\
89 \%\end{array}$ \\
\hline (i) Steppes ${ }^{b}\left[\mathrm{~km}^{2}\right]$ & 0 & 0 & 0 & 0 & 0 & 0 & 0 & 0 & 0 & 0 \\
\hline (ii) Arctic-alpine grasslands ${ }^{c}\left[\mathrm{~km}^{2}\right]$ & 0 & 450 & $\begin{array}{r}29,00 \\
0\end{array}$ & $\begin{array}{r}12,80 \\
0\end{array}$ & 4,000 & 200 & 0 & 0 & 0 & $\begin{array}{r}46,45 \\
0\end{array}$ \\
\hline $\begin{array}{l}\text { (iii) Azonal + extrazonal } \\
\text { grasslands }{ }^{\mathrm{d}}\left[\mathrm{km}^{2}\right]\end{array}$ & 500 & 50 & 2,000 & 150 & 1,000 & 50 & 150 & 50 & 100 & 4,050 \\
\hline (a) In good state $\left[\mathrm{km}^{2}\right]$ & 250 & NA & NA & NA & NA & NA & 150 & NA & NA & NA \\
\hline (b) Strongly degradede $\left[\mathrm{km}^{2}\right]$ & 250 & NA & NA & NA & NA & NA & 0 & NA & NA & NA \\
\hline (2) Secondary grasslands [km²] & 1,250 & 500 & 4,650 & 6,950 & $\begin{array}{r}16,85 \\
0\end{array}$ & 2,650 & 2,800 & 8,650 & 8,200 & $\begin{array}{r}52,50 \\
0\end{array}$ \\
\hline $\begin{array}{l}\text { - as fraction of their maximum area } \\
\text { (in the past) }\end{array}$ & $10 \%$ & $95 \%$ & $95 \%$ & NA & NA & NA & NA & $33 \%$ & NA & $\begin{aligned} & \text { ca. } \\
& 34 \%\end{aligned}$ \\
\hline (a) Semi-natural grasslands ${ }^{f}\left[\mathrm{~km}^{2}\right]$ & 550 & NA & NA & 400 & NA & 400 & 1,150 & 2,150 & 2,050 & $\begin{aligned} & \text { ca. } \\
& 22 \%\end{aligned}$ \\
\hline $\begin{array}{l}\text { (b) Strongly intensified } \\
\text { grasslands }\left[\mathrm{km}^{2}\right]\end{array}$ & 700 & NA & NA & 6,550 & NA & 2,250 & 1,650 & 6,450 & 6,150 & $\begin{array}{r}\text { ca. } \\
78 \%\end{array}$ \\
\hline
\end{tabular}

a HNV grasslands = natural grasslands in good state + semi-natural secondary grasslands.

b Steppes = climatogenic grasslands in regions where the climate is too dry to sustain forests.

c Arctic-alpine grasslands = climatogenic grasslands in regions where the climate is too cold to sustain forests.

d Azonal + extrazonal grasslands = pedogenic grasslands in forest climates, e.g. coastal dunes, salt marshes or grasslands of rocky outcrops, such as alvars.

e In good state vs. strongly degraded is roughly separated at a biodiversity loss of $50 \%$ (Dengler et al. 2020) 
f Semi-natural grasslands are those secondary grasslands that still contain at least $50 \%$ of the original biodiversity (Dengler et al. 2020), which is less strict than other definitions. Accordingly, also semi-improved grasslands as well as some grasslands that recovered or were restored from former arable fields and early successional stages of abandoned grasslands belong here.

g Strongly intensified grasslands are those secondary grasslands that host less than $50 \%$ of the typical biodiversity of "good" semi-natural grasslands (Dengler et al. 2020). Accordingly, also most temporary and frequently re-seeded grasslands belong here.

${ }^{1}$ Asssessed by H. H. Bruun based on national statistics.

2 Total grassland area from FAO (2019), based on CCI_LC for the year 2015; subcategories are rough estimates based on ecological knowledge.

${ }^{3}$ Asssessed by $\mathrm{H}$. Sickel based on national statistics.

${ }^{4}$ Asssessed by T. Birge based on national statistics.

5 Based on data from Török et al. (2018).

6 Semi-improved grasslands (included here in semi-natural grasslands s. I.) make up $15-20 \%$ of all secondary grasslands, in addition to $7.9 \%$ semi-natural ones in the stricter sense. Moreover, $1740 \mathrm{~km}^{2}$ of temporal grasslands were counted under grasslands following the definition of Dengler et al. (2020), while in other land use classifications they might be included in arable lands.

${ }^{7}$ Asssessed by $V$. Rašomavičius based on national statistics. 
Table 2. Natural and semi-natural grassland types of the Nordic-Baltic region, the corresponding vegetation types (syntaxa) and habitat types of the Habitats Directive and the threat status in the European Red List of Habitats. "Code" and "Name in the Red List" are according to Janssen et al. (2016) and Schaminée et al. (2016); the latter also contains distribution maps. "Corresponding vegetation type(s)" refer to phytosociological classes and in four widespread classes of semi-natural grasslands to phytosociological orders (in brackets). Classification is generally based on Mucina et al. (2016), but modified for the class Koelerio-Corynephoretea s. I. according to Dengler (2003). Orders (O.) are given only for the four widespread classes of semi-natural grasslands. "Corresponding habitat type(s)" lists the corresponding habitat types that are protected in European Union by the Habitats Directive (European Commission 2013), with * indicating priority habitats. "RL" finally gives the Red List status at European scale (EU28+; Janssen et al. 2016): CR = Critically Endangered, EN = Endangered, VU = Vulnerable, NT = Near Threatened, LC = Least Concern.

\begin{tabular}{|c|c|c|c|c|}
\hline Code & Name in Red List & $\begin{array}{l}\text { Corresponding } \\
\text { vegetation type(s) }\end{array}$ & $\begin{array}{l}\text { Cor } \\
\text { res } \\
\text { pon } \\
\text { din } \\
\text { g } \\
\text { hab } \\
\text { itat } \\
\text { typ } \\
\text { e(s) }\end{array}$ & $\mathbf{R L}$ \\
\hline \multicolumn{5}{|c|}{ Coastal habitats $(A, B)$} \\
\hline $\mathrm{A} 2.5 \mathrm{a}$ & Arctic coastal salt marsh & Juncetea maritimi & $\begin{array}{l}133 \\
0\end{array}$ & NT \\
\hline $\mathrm{A} 2.5 \mathrm{~b}$ & Baltic coastal meadow & Juncetea maritimi & $\begin{array}{l}163 \\
0^{*}\end{array}$ & EN \\
\hline $\mathrm{A} 2.5 \mathrm{c}$ & Atlantic coastal salt marsh & Juncetea maritimi & $\begin{array}{l}132 \\
0 \\
133 \\
0\end{array}$ & VU \\
\hline $\mathrm{B} 1.3 \mathrm{a}$ & Atlantic and Baltic shifting coastal dune & Ammophiletea & $\begin{array}{l}211 \\
0 \\
212 \\
0\end{array}$ & NT \\
\hline $\mathrm{B} 1.4 \mathrm{a}$ & Atlantic and Baltic coastal dune grassland (grey dune) & $\begin{array}{l}\text { Koelerio- } \\
\text { Corynephoretea } \\
\text { (Corynephoretalia } \\
\text { canescentis, Sedo acris- } \\
\text { Festucetalia) }\end{array}$ & $\begin{array}{l}213 \\
0^{*}\end{array}$ & VU \\
\hline B3.4a & Atlantic and Baltic soft sea cliff & various & $\begin{array}{l}123 \\
0\end{array}$ & LC \\
\hline \multicolumn{5}{|c|}{ Grassland (E) } \\
\hline E1.1a & Pannonian and Pontic sandy steppe & $\begin{array}{l}\text { Koelerio- } \\
\text { Corynephoretea (Sedo } \\
\text { acris-Festucetalia) }\end{array}$ & $\begin{array}{l}234 \\
0 / \\
612 \\
0^{*}\end{array}$ & $\mathrm{CR}$ \\
\hline $\mathrm{E} 1.1 \mathrm{~b}$ & $\begin{array}{l}\text { Cryptogam- and annual-dominated vegetation on siliceous rock } \\
\text { outcrops }\end{array}$ & $\begin{array}{l}\text { Koelerio- } \\
\text { Corynephoretea (Sedo- } \\
\text { Scleranthetalia) }\end{array}$ & $\begin{array}{l}823 \\
0\end{array}$ & VU \\
\hline
\end{tabular}


E1.1d Cryptogam- and annual-dominated vegetation on calcareous and ultramafic rock outcrops

E1.2a Semi-dry perennial calcareous grassland

E1.7 Lowland to submontane, dry to mesic Nardus grasland

E1.9a Oceanic to subcontinental inland sand grassland on dry acidic and neutral soils

E1.9b Inland sanddrift and dune with siliceous grassland

E2.1a Mesic permanent pasture of lowlands and mountains

E2.2 Low and medium altitude hay meadow

E2.3 Mountain hay meadow

E3.4a Moist or wet mesotrophic to eutrophic hay meadow

E3.4b Moist or wet mesotrophic to eutrophic pasture

E3.5 Temperate and boreal moist or wet oligotrophic grassland

E4.1 Vegetated snow patch

E4.3a Boreal and arctic acidophilous alpine grassland

E4.4a Arctic-alpine calcareous grassland

E5.2a Thermophilous woodland fringe of base-rich soils

E5.2b Thermophilous woodland fringe of acidic soils

E5.3 Pteridium aquilinum stand
Koelerio-

$628 \mathrm{VU}$

Corynephoretea (Alysso $0^{*}$

alysssoidis-Sedetalia)

824

$0^{*}$

Festuco-Brometea

621 VU

(Brachypodietalia

pinnati)

$0\left(^{*}\right)$

627

0 *

Nardetea strictae

$623 \mathrm{VU}$

(Nardetalia strictae)

$0^{*}$

Koelerio-

233 EN

Corynephoretea (Trifolio

arvensis-Festucetalia

ovinae)

Koelerio-

233 EN

Corynephoretea

(Corynephoretalia

canescentisa)

627

$0^{*}$

Molinio-Arrhenatheretea

(Arrhenatheretalia

$627 \mathrm{VU}$

elatioris)

$0 *$

651

0

Molinio-Arrhenatheretea

(Arrhenatheretalia

627 VU

elatioris)

0 ,

651

0

Molinio-Arrhenatheretea 652 VU

(Poo alpinae-Trisetetalia) 0

Molinio-Arrhenatheretea 641 EN

(Molinietalia caeruleae) 0

Molinio-Arrhenatheretea $641 \quad$ EN

(Molinietalia caeruleae) 0

Molinio-Arrhenatheretea 641 EN (Molinietalia caeruleae) 0 ,

643

0 ,

644

0 ,

645

0

Salicetea herbaceae

$-\quad$ VU

Juncetea trifidi

615 LC

0

Saxifrago cernuae-

Cochlearietea

617 LC

groenlandicae, Carici

rupestris-Kobresietea

bellardii, Elyno-

Seslerietea

$\begin{array}{lll}\text { Trifolio-Geranietea } & - & \text { NT } \\ \text { sanguinei } & & \\ \begin{array}{l}\text { Trifolio-Geranietea } \\ \text { sanguinei }\end{array} & - & \text { LC } \\ \begin{array}{l}\text { Trifolio-Geranietea } \\ \text { sanguinei }\end{array} & - & \text { LC }\end{array}$


E5.4 Lowland moist or wet tall-herb and fern fringe

E5.5 Subalpine moist or wet tall-herb and fern fringe

E7.2 Hemiboreal and boreal wooded pasture and meadow
Epilobietea angustifolii

643

VU

Mulgedio-Aconitetea

LC

various

653 CR 
Table 3. Overview of the main drivers of grassland biodiversity loss across the Nordic-Baltic region, their current impact (i.e. rate of biodiversity loss caused by them 2010-2019) and its anticipated future change (i.e. change in the rate of biodiversity loss in 2020-2029 compared to the situation in 20102019). "Current impact" is given on a five-step ordinal scale (none - low - medium - high - very high), while "Future change" was assessed on a three-step ordinal scale ("decrease" - " \pm constant" "increase"), where " \pm constant" means that the biodiversity loss due to this driver is expected to continue in the next decade at the same level as in the previous decade $( \pm 10 \%)$. Please note that in order to get an assessment of the expected impact during the next decade, both columns have to be combined: For example, if the current impact is "medium" and the future change is predicted to be an "increase", the future impact would be "high" (or even "very high"). Likewise, even if the importance of a driver is predicted to decrease, it will in most cases still cause additional biodiversity loss during the next decade. "NA" = not assessed.

\begin{tabular}{|c|c|c|}
\hline Driver & $\begin{array}{l}\text { Current } \\
\text { impact }\end{array}$ & Future change \\
\hline \multicolumn{3}{|l|}{ Habitat loss } \\
\hline Conversion to arable land & Low & \pm Constant \\
\hline Afforestation & Medium & \pm Constant \\
\hline Mining and energy production & Low & \pm Constant \\
\hline Settlements and other infrastructure & Low & \pm Constant \\
\hline \multicolumn{3}{|l|}{ Changes in grassland management } \\
\hline Abandonment and underuse & High & Increase \\
\hline Overgrazing & Medium & \pm Constant \\
\hline Other forms of intensification & High & \pm Constant \\
\hline \multicolumn{3}{|l|}{ Altered site conditions } \\
\hline Eutrophication (direct and indirect) & Medium & \pm Constant \\
\hline Altered water regime & Low & \pm Constant \\
\hline Climate change & Low & Increase \\
\hline Invasive species & Low & \pm Constant \\
\hline \multicolumn{3}{|l|}{ Direct impact of humans and their infrastructure } \\
\hline Military and armed conflicts & None & \pm Constant \\
\hline Recreation activities & Low & \pm Constant \\
\hline Collecting wild plants and hunting & Low & \pm Constant \\
\hline Wildlife loss due to electrocution, wind farm collision or traffic & Low & \pm Constant \\
\hline Wildfires caused by humans & None & NA \\
\hline
\end{tabular}

